\title{
Study on the Relationship Between Deccan LIPs and Chicxulub Crater Based on "Collisions Aggregation Effect"
}

\author{
Liu Chenming, Yang Demin \\ Resource Exploration Institute, Yunnan Land and Resources Vocational College, Kunming, China
}

Email address:

xiao6yu2000@aliyun.com (Liu Chenming)

To cite this article:

Liu Chenming, Yang Demin. Study on the Relationship Between Deccan LIPs and Chicxulub Crater Based on "Collisions Aggregation Effect". Earth Sciences. Vol. 7, No. 2, 2018, pp. 64-73. doi: 10.11648/j.earth.20180702.14

Received: February 2, 2018; Accepted: February 24, 2018; Published: March 20, 2018

\begin{abstract}
Based on the previous studies, the author has proposed that the "Collisions Aggregation Effect" by the impact of a celestial body in the geological academic circles, which can lead to the endogenic process of the "collisions aggregation point", the formation of volcanic eruptions and even the formation of LIPs. According to the principle of physics, this article further theoretically enriched the content of "Collisions Aggregation Effect" on the previous work and put forward the linear "Collisions Aggregation Effect" and nonlinear "Collisions Aggregation Effect". On the basis of the global paleo-plate and paleogeographic data, this paper takes the Deccan LIPs and the Chicxulub crater as the research objects and conducts the research work based on the "Collisions Aggregation Effect". The main conclusions are as follows: 1. The main eruption time of the Deccan LIPs is 66 Ma, while the Chicxulub crater was formed at about $65 \mathrm{Ma}$ in approximate time; 2. At $65 \mathrm{Ma}$, the Deccan LIPs are located at $35^{\circ} \mathrm{S}$, $65^{\circ} \mathrm{E}$, while the Chicxulub Crater is located at $20^{\circ} \mathrm{N}, 50^{\circ} \mathrm{W}$, both of which have the characteristics of the distribution of nonlinear "Collisions Aggregation Effect" on the Earth; 3. A Severe meteorite impact occurred at the Chicxulub crater in the Gulf of Mexico, causing "Collisions Aggregation Effect", which may be an important reason for the formation of the Deccan LIPs; 4. The velocity vector direction of the Chicxulub meteorite may not be exactly pointing to the Earth's center, but is a little south-easterly direction; 5. Using the "Collisions Aggregation Effect" for the "impact point" or "collisions aggregation point" geographic location constraints, but also should taking into account the celestial body impact velocity vector direction; 6 . May be precisely because of the meteorite impact and the Deccan LIPs formed by the "Collisions Aggregation Effect" of the Chicxulub crater impact caused the massive dinosaur-based mass extinctions at the $65 \mathrm{Ma}$ of the $\mathrm{K} / \mathrm{T}$ boundary and accelerated the Indian Plate drift.
\end{abstract}

Keywords: Deccan LIPs, Chicxulub Crater, "Collisions Aggregation Effect", Celestial Body Impact, K/T, Paleogeography

\section{Introduction}

Based on the previous studies [1], the author has proposed that the "Collisions Aggregation Effect" by the impact of a celestial body collisions in the geological academic circles, which can lead to the endogenic process of the "collisions aggregation point", the formation of volcanic eruptions and even the formation of LIPs [2-4]. The proposed hypothesis provides a new thought and direction to the research on the genesis of LIPs. In recent years, geologists both at home and abroad have made many achievements and understanding in the recognition of LIPs and the discovery of meteorite craters. According to Hartmann [5], the probability of the impact of various extraterrestrial materials in the history of the earth, that a craters larger than $20 \mathrm{~km}$ in diameter formed is about
$0.36 \times 10^{-14} \mathrm{~km}^{2} / \mathrm{a}$ on the earth's surface, with an average diameter of about $30 \mathrm{Ma}$, but most of them are hard to discern due to the influence of later geological process. The number of craters currently discovered and identified in the world may reach hundreds of locations. With the application of new detection technologies, the number of craters may continue to increase. According to statistics by Ren Zhenqiu [6], the impact time of the 24 craters with diameter more than $25 \mathrm{~km}$ around the world at present, depends on their respective size with the boundary of the era, period, epoch or stage, that have a good corresponding relationship. And the 3 craters with a diameter of more than $160 \mathrm{~km}$ have the impact time of $65 \mathrm{Ma}$, $570 \mathrm{Ma}$ and $1850 \mathrm{Ma}$, which respectively correspond to the boundary of the Mesozoic and Cenozoic, Proterozoic and Paleozoic, Paleoproterozoic and Mesoproterozoic; The 7 
craters with the diameter of $54-100 \mathrm{~km}$, of which the 6 occurred at the boundary of the period, the other one is not at the boundary of the period, but also fell in the boundary of a series of major geological events. Recent studies have revealed that it has formed four large igneous provinces (Emeishan LIPs, Siberia LIPs, Himalaya-Panjia LIPs and Deccan LIPs) in the Asian continent since the Late Permian [7]. However, there is no scholar has ever paid attention to the relationship between the meteorite impact events and the LIPs during the history of the Earth. What is the relationship? This article is based on the question and the "Collisions Aggregation Effect " under the premise that carrying out this research work. And under the work of the author, with the Chicxulub crater and the Deccan LIPs as the research object, on the basis of the global paleogeographic data about $65 \mathrm{Ma}$, it is concluded that $65 \mathrm{Ma}$ ago, the Chicxulub crater and the Deccan LIPs are not in the symmetric point with the Earth as its center of symmetry in the ancient geography, but it is corresponding to the nonlinear "Collisions Aggregation
Effect " proposed by the author; The formation of the time of the Chicxulub crater and the Deccan LIPs tend to be at the same time in general. So, The author believes that the relationship between the Chicxulub crater and the Deccan LIPs should have the following characteristics: 1 . The two are approximate in time. Some studies have shown that the formation time of the Chicxulub crater is about $65 \mathrm{Ma}$ [8], while the Deccan LIPs is about $66 \mathrm{Ma}$ [9-11]. 2. The two have the characteristics of the distribution of nonlinear "Collisions Aggregation Effect" on the Earth; 3. The meteorite impact occurred at the Chicxulub crater in the Gulf of Mexico, causing the"Collisions Aggregation Effect", which may be the main reason for the formation of the Deccan LIPs. Does this relationship characteristics between the Chicxulub crater and the Deccan LIPs explain the practical and universal characteristics of the "Collisions Aggregation Effect" from the impact of a celestial body? Has it verified that the "Collisions Aggregation Effect" from the impact of a celestial body?

\subsection{Deccan LIPS}

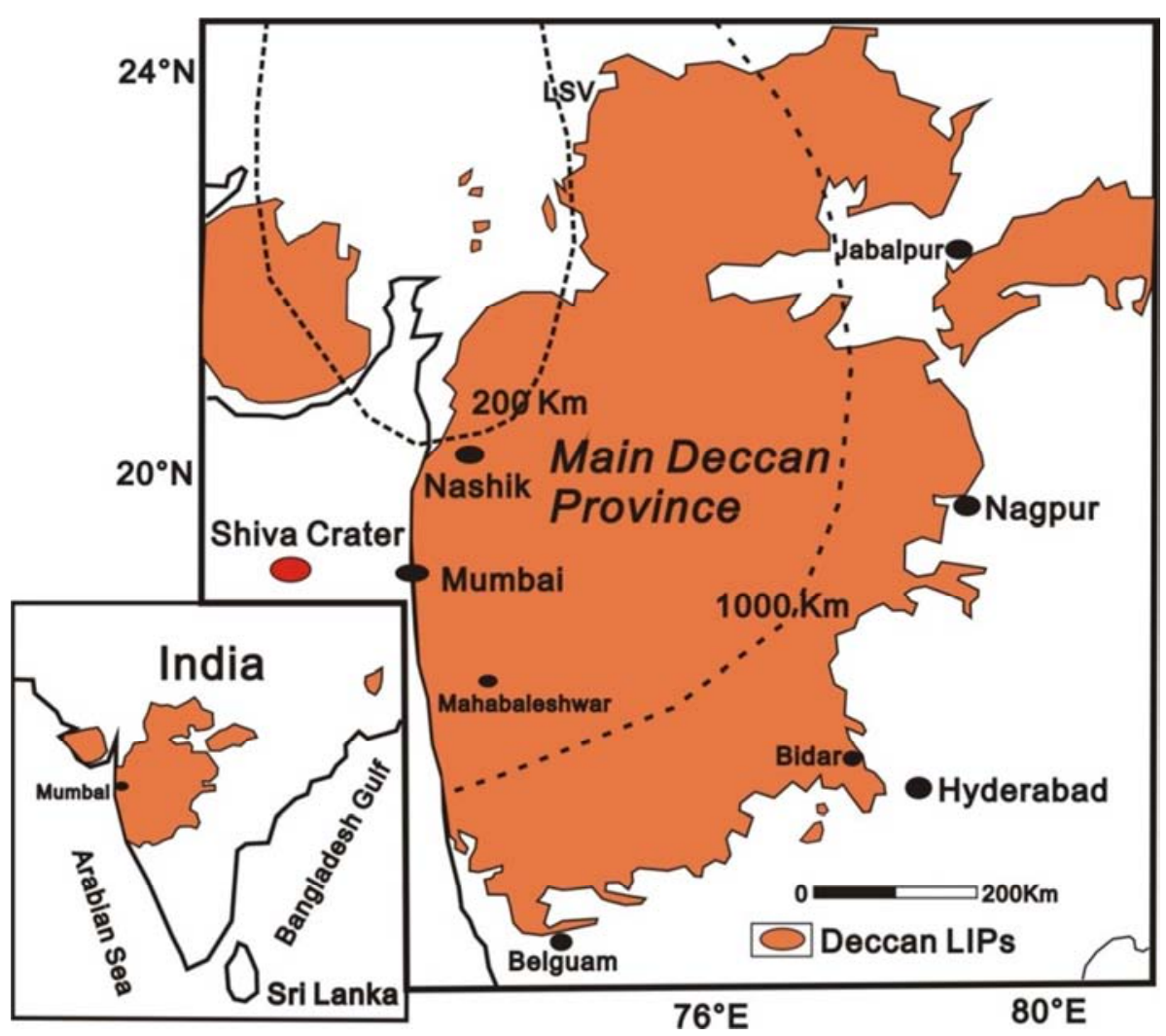

Figure 1. Distribution of basalts in the Deccan large igneous province (Modified) [6], [24].

In the Figure 1, the Deccan Traps or Deccan LIPs (DLIP) are a large igneous province located on the Deccan Plateau of west-central India $\left(17^{\circ}-24^{\circ} \mathrm{N}, 73^{\circ}-74^{\circ} \mathrm{E}\right)$ and are one of the largest volcanic features on Earth. They consist of multiple layers of solidified flood basaltthat together are more than $2,000 \mathrm{~m}(6,600 \mathrm{ft})$ thick, cover an area of c. $500,000 \mathrm{~km}^{2}$ $(200,000 \mathrm{sq} \mathrm{mi})$ [12], and have a volume of c. 1,000,000 $\mathrm{km}^{3}(200,000 \mathrm{cu} \mathrm{mi})[13]$. Originally, the Deccan LIPs may have covered c. $1,500,000 \mathrm{~km}^{2}(600,000 \mathrm{sq} \mathrm{mi})$ [14], with a correspondingly larger original volume. It is generally accepted that the Deccan LIPs were generated when the Indian continent moved northward to the Réunion mantle plume about $56 \mathrm{Ma}$ ago [9-11]. The Deccan LIPs is mainly composed of the differentiation of tholeiite and a small amount of basaltic andesite. In addition, there is very little picrite, picrite basalt, alternating layers of rich potassium lava, differentiation 
of felsic rocks and alkaline intrusive body. At present, the area of the Deccan LIPs distributed on land is about $5 \times 105 \mathrm{~km}^{2}$, and its original eruption volume is estimated to be $0.75-1.5 \times 106 \mathrm{~km}^{3}$. Due to the subsidence during the Cenozoic, the Deccan LIPs also have a large area of distribution in the offshore areas of western India. It is estimated that the initial area of Deccan LIPs is about $1.5 \times 106 \mathrm{~km}^{2}$. The basement of the Deccan Igneous Province consists mainly of the Archean and Proterozoic landmass, covered with young sediments. The Deccan LIPs are best known and widely discussed in all LIPs because of its main eruptions period along with the Cretaceous-Tertiary Boundary (KTB) [15-18]. The earliest (68 Ma) magmatism product of the Deccan LIPs was characterized by a small amount of alkaline volcanic rocks and intrusive rocks that occurred in the north [17] and gradually evolved into large-scale tholeiite lava eruptions in the Main Deccan Province. The flood basalts magmatism started at about $67 \mathrm{Ma}$ and gradually moved from the north to the south, and the last flood basalts eruption occurred in the southern margin of the Main Deccan Province in the Early Paleocene (64 Ma) [18-19]. The rhyolitic, trachyte and basaltic eruptions (62-64 Ma) occurred in the Mumbai area [20-22], which developed in a newly formed shallow gulf. Due to the fall of the continental crust and seawater intrusion [23], the gulf was formed along the thinned margins of the Indian landmass before the final separation of the Seychelles-Mascarene microcontinent from the Indian landmass at 62-64 Ma [24]. Saundersren [25] suggested that the Deccan LIPs may start $67 \mathrm{Ma}$ and end $61 \mathrm{Ma}$, but the main eruptive activity of the Deccan LIPs occurs between 66-65 Ma with a time limit of only $0.5-1 \mathrm{Ma}$.

\subsection{The Chicxulub Crater}

In the Figure 2, according to the Wikipedia, the Chicxulub crater is an impact crater buried underneath the Yucatán Peninsulain at the Mexico [26]. Its center is located near the town of the Chicxulub, after which the crater is named. It was formed by a impact from a large asteroid or comet about 10 to 15 kilometres (6.2 to 9.3 miles) in diameter [27], the Chicxulub impactor, striking the Earth. The date of the impact coincides precisely with the Cretaceous-Paleogene Boundary (K-Pg Boundary), slightly less than 66 million years ago, and a widely accepted theory is that worldwide climate disruption from the event was the cause of the Cretaceous-Paleogene extinction event, a mass extinction in which $75 \%$ of plant and animal species on Earth suddenly became extinct, including all non-avian dinosaurs. The crater is more than 180 kilometres (110 miles) in diameter and $20 \mathrm{~km}$ (12 mi) in depth, well into the continental crust of the region of about $10-30 \mathrm{~km}$ (6.2-18.6 mi) depth. It makes the feature the third of the largest confirmed impact structures on Earth, and the only one whose peak ring is intact and directly accessible for scientific research [28].

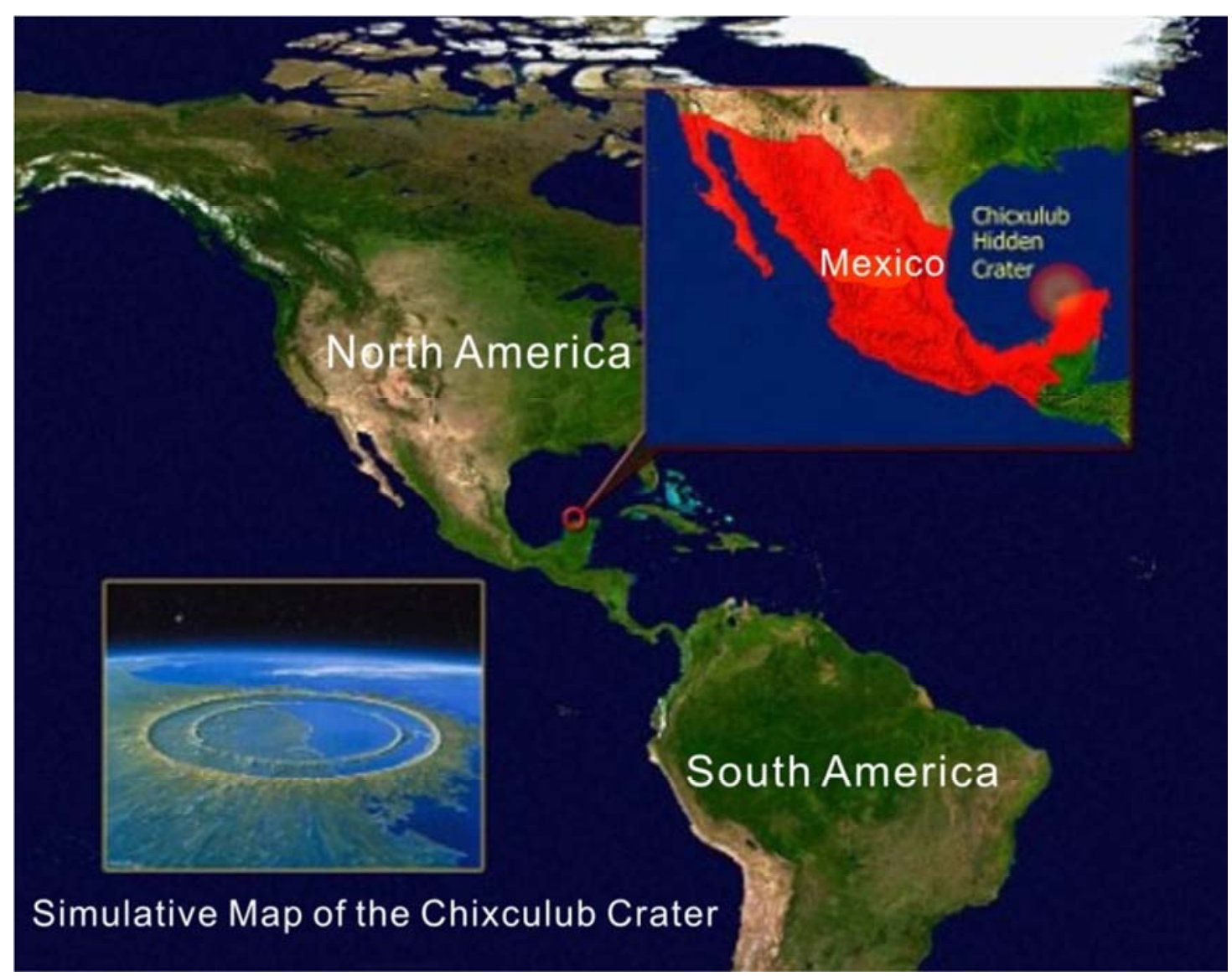

(according to https://www.ufochn.comthread-15306-1-1.html.jpg)

Figure 2. The Chicxulub crater current location map. 


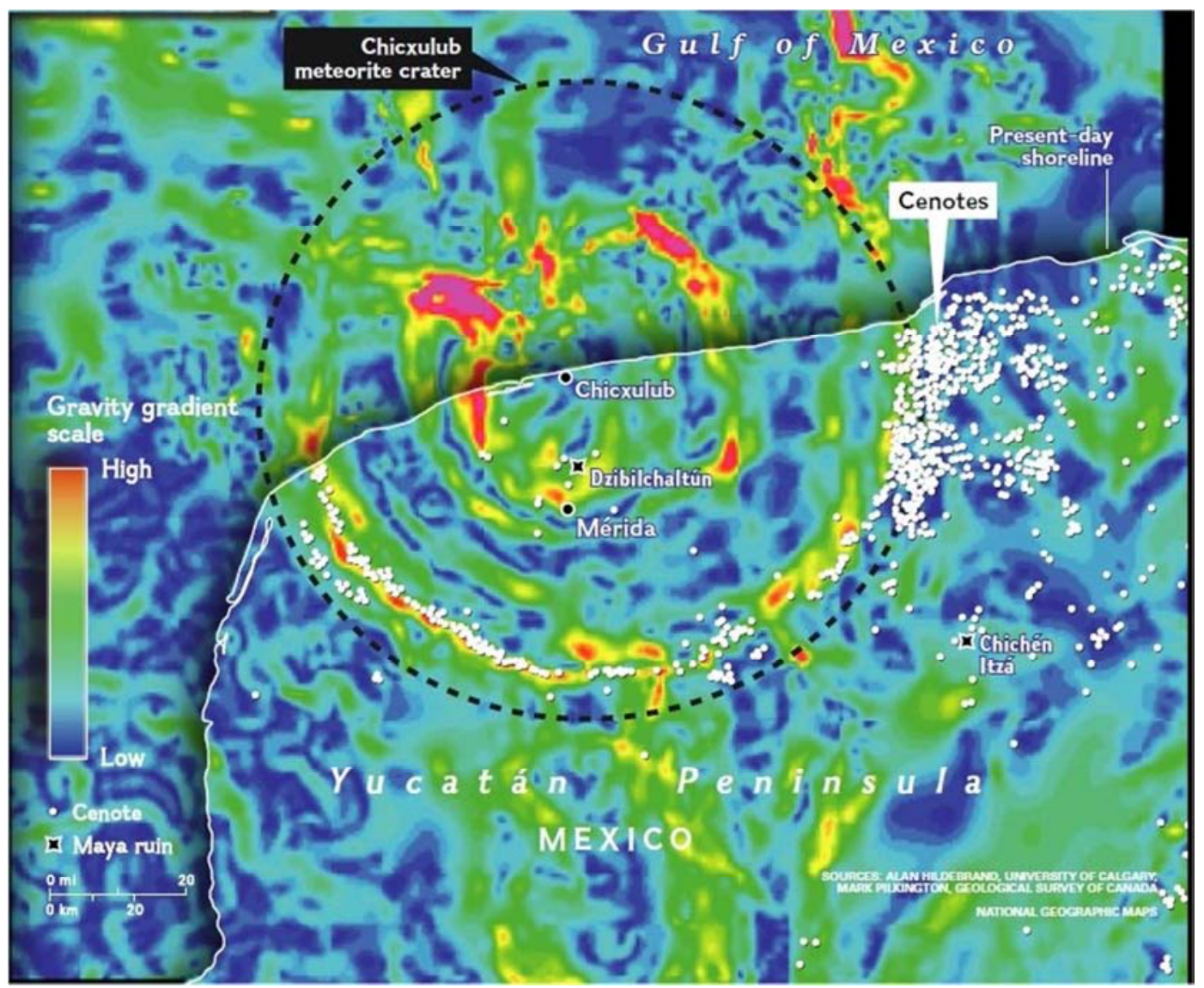

(according to https://en.wikipedia.org/wiki/Chicxulub_crater\#cite_note-6)

Figure 3. The gravity anomaly map of the Chicxulub crater.

The crater was discovered by Antonio Camargo and Glen Penfield, geophysicists who had been looking for petroleum in the Yucatán during the late 1970s. Penfield was initially unable to obtain evidence that the geological feature was a crater and gave up his search. Later, through contact with Alan Hildebrand in 1990, Penfield obtained samples that suggested it was an impact feature. Evidence for the impact origin of the crater includes shocked quartz [29], a gravity anomaly, and tektites in surrounding areas (Figure 3). In 2016, a scientific drilling project drilled deep into the peak ring of the impact crater, hundreds of meters below the current sea floor, to obtain rock core samples from the impact itself. The discoveries were widely seen as confirming current theories related to both the crater impact and its effects.

\section{2. "Collisions Aggregation Effect" of a Meteorite Impact}

The author believes that the violent celestial body impact event can cause "Collisions Aggregation Effect" and form a large igneous province at the "collisions aggregation point"[2-4]. However, not every impact and the "Collisions Aggregation Effect" caused by a celestial body impact can create a magmatic activities, volcanic eruptions or LIPs, it may be determined by factors such as the size of the celestial body, the velocity, the direction of the impact velocity vector, and the geographical location of the impact point.

\subsection{Linear "Collisions Aggregation Effect"}

Figure 4a shows the "Collisions Aggregation Effect" of the vector of impact velocity of the celestial body pointing to the Earth's center. It shows the destruction of the two points "impact point and collisions aggregation point"[2-4], that due to the violent impact of extraterrestrial celestial bodies, and the "impact point, collisions aggregation point" and the Earth's center should be in a straight line. Due to the violent impact of the celestial bodies, the author believes that not only the "impact point" can cause a violent endogenic process and magmatism [30], but also the " collisions aggregation point " may create a violent magmatic activities and even a large igneous provinces. In Figure $4 \mathrm{~b}$, the author believes that when the impact velocity vector of the celestial body pointing to the Earth's center, the geographical relation of the two points "impact point and collisions aggregation point" should have the point-symmetric position characteristics of the earth's center on the earth, namely: latitude symmetry, and the meridian is the same. The author defines this feature represented by Figure $4 \mathrm{a}$ and Figure $4 \mathrm{~b}$ above as the Linear "Collisions Aggregation Effect".

\subsection{Nonlinear "Collisions Aggregation Effect"}

In Figure 5, when the impact velocity vector of a celestial 
body is not pointing to the Earth's center, the position of the "collisions aggregation point" may be "a" or "b" or "a" to "b" location, this feature is the Nonlinear "Collisions Aggregation Effect". If the velocity vector direction of the celestial body point to the center of the Earth, the linear "Collisions Aggregation Effect " is stronger at the "collisions aggregation point". During the history of the Earth, it is possible that most of the impact velocity vector of celestial bodies are not pointing to the Earth's centet.

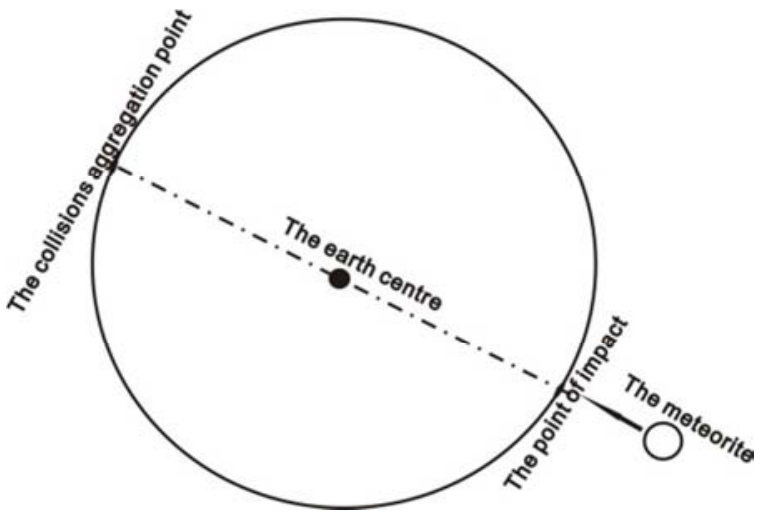

a. Diagram of the "Collisions Aggregation Effect" of a meteorite impact

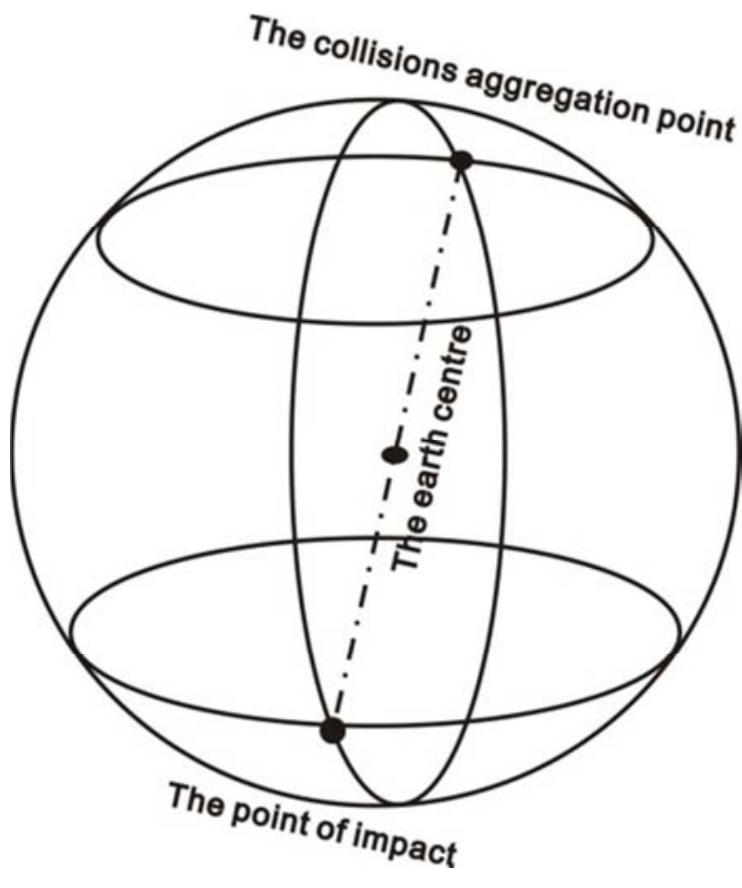

b. The geographical location of the two point

Figure 4. A model of the linear "Collisions Aggregation Effect".

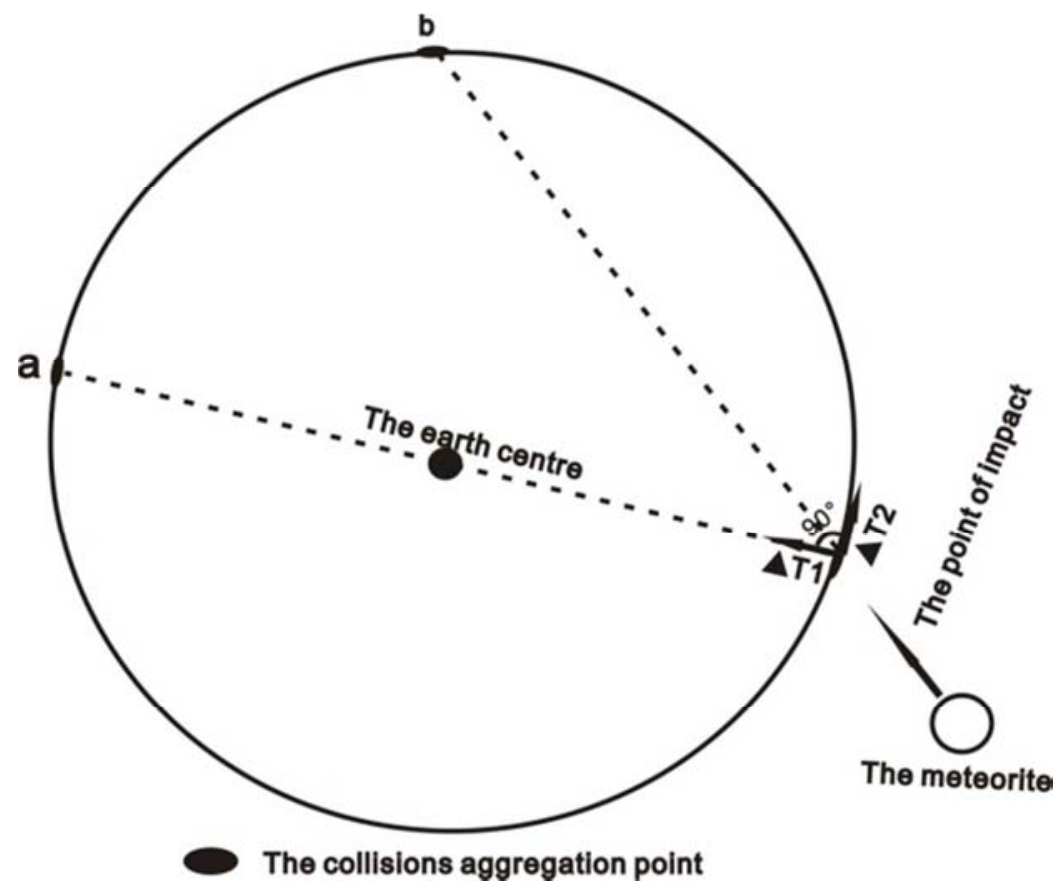

Figure 5. A model of the nonlinear "Collisions Aggregation Effect".

\section{The Relationship Between the Deccan LIPs and the Chicxulub Crater}

\subsection{Time Relationship}

The main forming time of the Deccan LIPs was $66 \mathrm{Ma}$ [9-11], while the Chicxulub crater in the Gulf of Mexico formation time was about $65 \mathrm{Ma}$ [8]. Therefore, the two have the approximate simultaneous relations.

\subsection{Positional Relationship}

According to the research on the global paleogeographic restoration at the $\mathrm{K} / \mathrm{T}$ boundary about $65 \mathrm{Ma}$, concluded that the Deccan LIPs were located at $35^{\circ} \mathrm{S}, 65^{\circ} \mathrm{E}$, and the Chicxulub crater was located at $20^{\circ} \mathrm{N}, 50^{\circ} \mathrm{W}$ (Figure 6, Figure 7a) [31-32]. According to the Figure $7 \mathrm{a}$, the author finds that the two locations do not have the distribution rule of the linear "Collisions Aggregation Effect", but similar to the nonlinear 
"Collisions Aggregation Effect" (Figure 5).

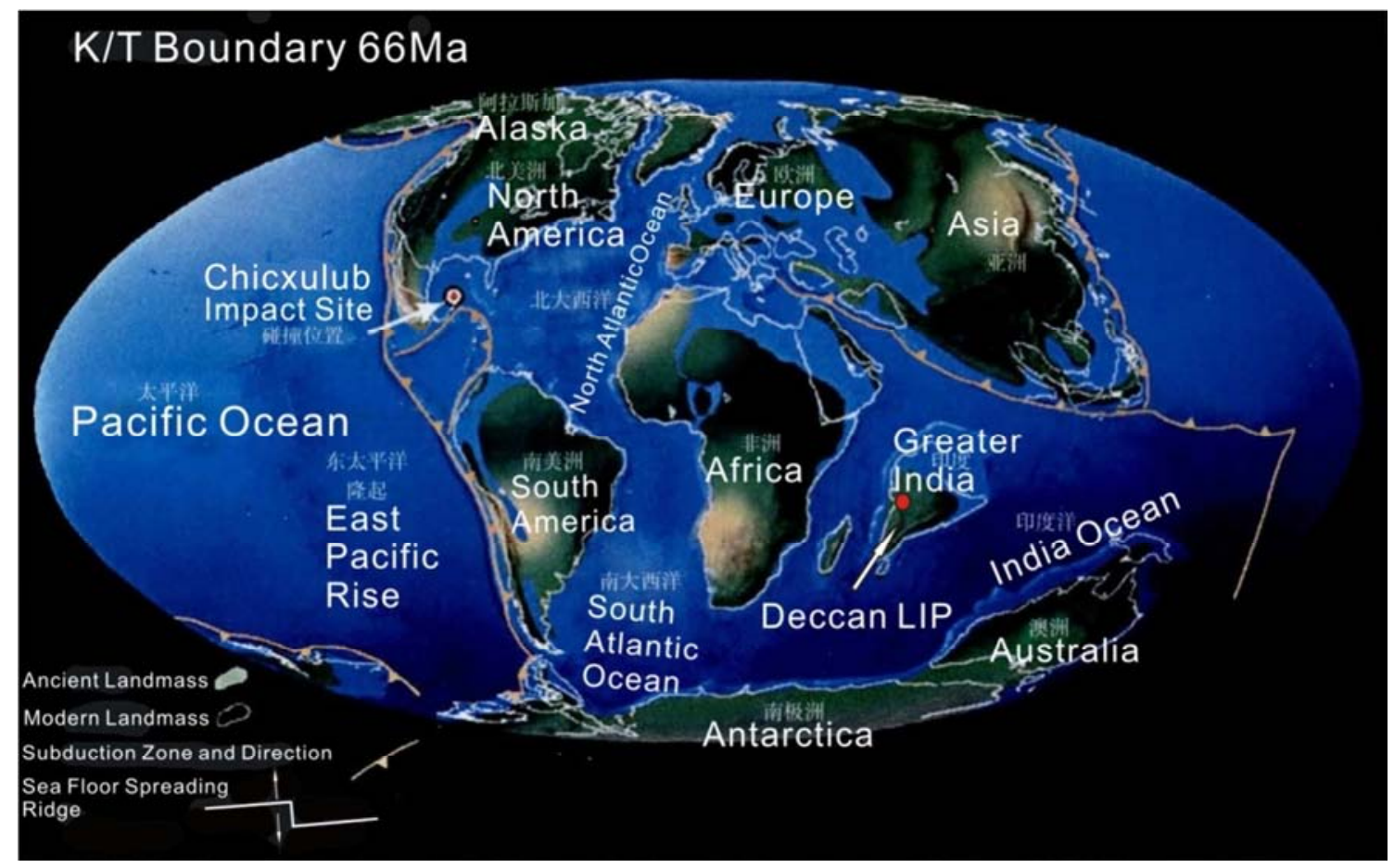

(according to http://www.bioon.com/popular/dili/89690.shtml)

Figure 6. The global paleogeographic recovery map of the K/T Boundary.

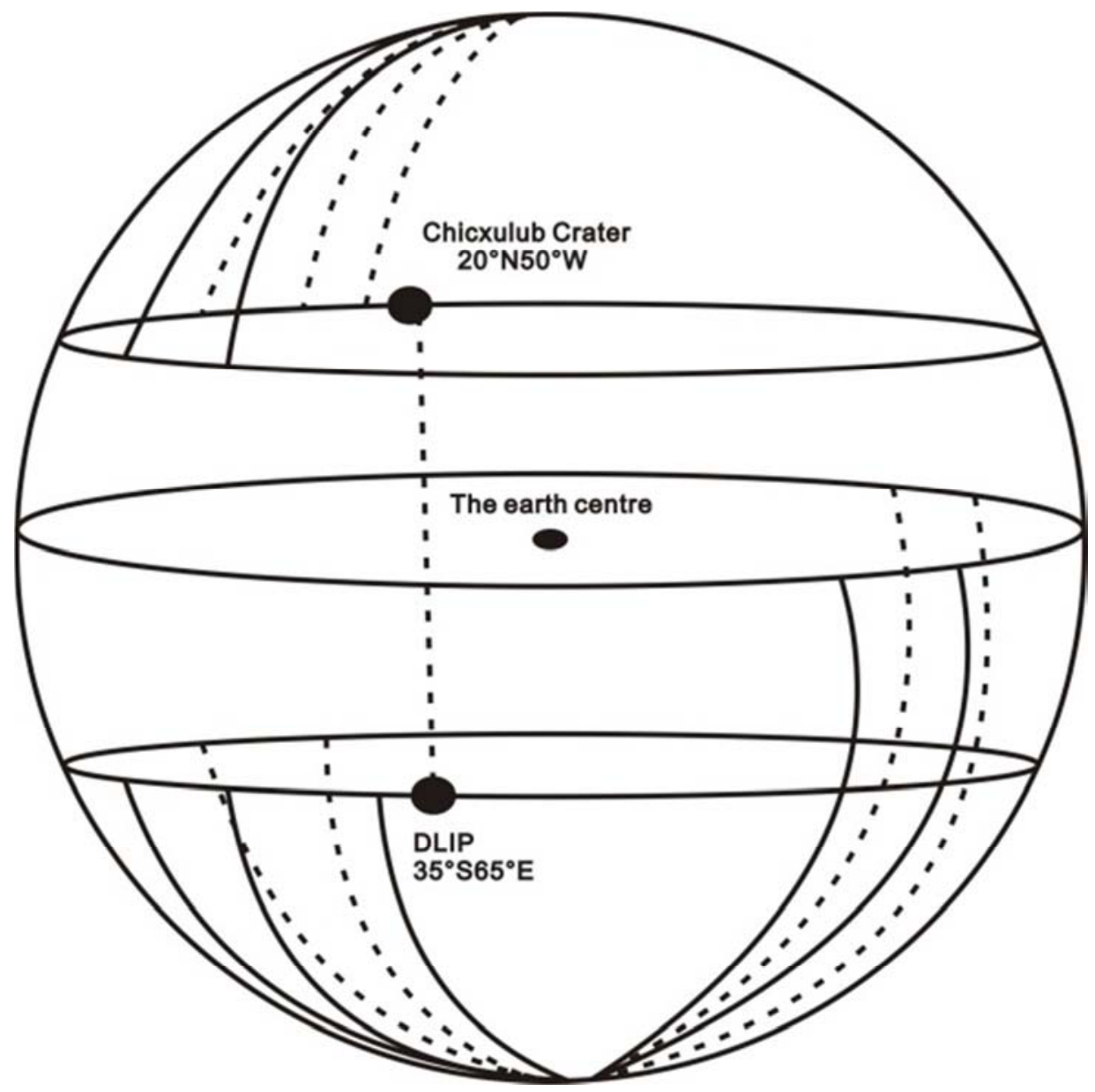

a. DLIP and Chixculub crater relative position diagram at the $\mathrm{K} / \mathrm{T}$ boundary 


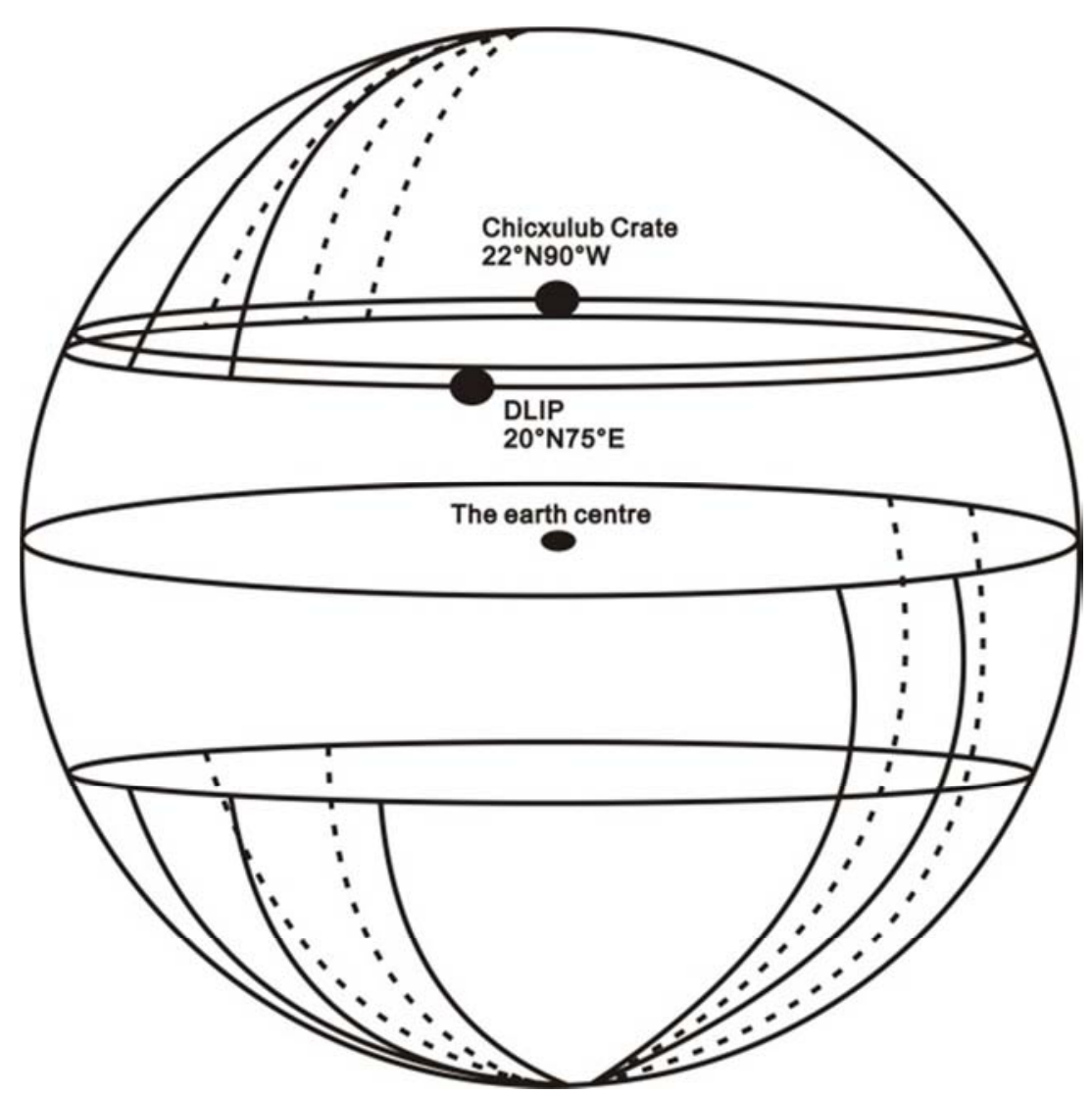

b. Current relative position of the DLIP and Chicxulub crater diagram

Figure 7. Deccan LIPs (DLIP) and Chixculub crater relative position diagram.

At this point, consider that the relationship between the Deccan LIPs and the Chixculub crater is characterized by the following characteristics: 1 . The formation time of the two is approximately simultaneity; 2. The two are spatially distributed in a nonlinear "Collisions Aggregation Effect"; 3. The "Collisions Aggregation Effect" caused by a dramatic meteorite impact at the Chicxulub crater in the Gulf of Mexico $65 \mathrm{Ma}$ ago, which may be one of the important reasons for the formation of the Decan LIPs. 4. The velocity vector direction of the Chicxulub meteorite may not be exactly pointing to the Earth's center, but is a little south-easterly direction.

\section{Discussion}

Based on the above results, the author thinks the following points need to be discussed:

(i). The "Collisions Aggregation Effect" of a meteorite impact proposed by the auothor is a idealized model [2-4], the earth is assumed to be a standard sphere, and the impact velocity vector direction is pointing to the Earth's center, then form a distribution characteristic of the linear "Collisions Aggregation Effect"(Figure 4). In Figure 5, when the direction of the impact velocity of the celestial body does not point to the center of the Earth, the position of "collisions aggregation point" may be "a" or "b" or somewhere of the "a" to "b". In Figure 5, if the direction of the impact vector of a celestial body points to the Earth's center, the "Collisions Aggregation
Effect" is stronger at the "collisions aggregation point", because the " $\boldsymbol{\Delta} \mathrm{T} 2$ " component is smaller, dispersed energy is smaller. However, based on the paleogeographical positions of the Deccan LIPs and the Chixculub crater, the author thinks the velocity vector direction of the meteorite hit the Chixculub $65 \mathrm{Ma}$ ago may not be pointing to the center of the Earth but may be the southeastern direction and cause the decreases in longitude and latitude moves south at the "collisions aggregation point"(relative to the linear"Collisions Aggregation Effect"). For the celestial bodies that hit the Earth during the historical period, the directions of the impact velocity vector are not necessarily exactly pointing to the Earth's center, and not every impact and the "Collisions Aggregation Effect" caused by a celestial body impact can create a magmatic activities, volcanic eruptions or LIPs, it may be determined by factors such as the size of the celestial body, the velocity, the direction of the impact velocity vector, the components of the planet, the geographical location of the impact point and others. Therefore, it is difficult to strictly quantify the geographical position constraints of the "impact point" or "collisions aggregation point" using the "Collisions Aggregation Effect", and the resulting geographical location may not be unique or accurate. At present, about the simulated impact experiment which the velocity vector direction is not pointing to the Earth's center, the author has not collected related papers and experimental data and even has not carried out any relevant experiments. In this regard, the author will 
continue to pay attention;

(ii). Using the "Collisions Aggregation Effect" to carry out paleogeographic restoration research on the "collisions aggregation point" or "impact point", it need to use the latitude and longitude data of higher accuracy. However, judging from the global perspective, the latitude and longitude data of the relevant landmass vary in their opinions and none is entirely credible. In particular, the restoration of the paleogeographic longitude at home and abroad is still difficult and no series of results have yet emerged. Therefore, this has a great impact on the author's research work, but also brings uncertainty to the author's research results.

(iii). The author noticed that there was a giant Shiva Crater distribution near the Deccan LIPs (Figure 1) and the impact time was almost exactly the same as that of the Deccan LIPs [33-34]. A. P. Jones [30] suggested that the violent celestial body impact could lead to the formation of the magmatism, volcanic eruptions and even LIPs at the "impact point". Therefore, the author believes that the impact event represented by the Shiva Crater may also be one of the reasons that lead to the formation of the Deccan LIPs.

(iv). At the K/T boundary period, around $65 \mathrm{Ma}$, a asteroid hit at $20^{\circ} \mathrm{N}, 55^{\circ} \mathrm{W}$ (the paleogeographic geographical location of the Chicxulub) and the impact point was located in the North Atlantic (Figure 6). There are reports that at 65 Ma there is a large area regression, a decline in sea level and a significant warming of the ocean [35-36], the author thinks this may have a direct relationship with the impact point exactly in ocean [37];

(v). It has been reported [38] that the Indian Plate drifts suddenly to a very rapid rate of about $20 \mathrm{~cm} / \mathrm{a}$ after about 65 $\mathrm{Ma}$ at the K/T boundary [39]. At this juncture of time, the author had to be reminded of the relationship with the celestial body impact incident. And thinks that there are two kinds of situations if the velocity vector direction of celestial body impact does not exactly point to the Earth's center in Figure 5: (1) When the velocity vector direction of the celestial body exist in a velocity component ( $\boldsymbol{\Delta} \mathrm{T} 2)$ which is consistent with the sense of rotation of the Earth, it will speed up the Earth's rotation speed; (2) When the velocity vector direction of the celestial body exist in a velocity component with opposite direction of the Earth's rotation speed, it will slows the Earth's rotation speed. Through the paleogeographic restoration research, the author believes that the velocity vector direction of the celestial body that hit the Chixculub $65 \mathrm{Ma}$ ago should not be pointing to the Earth's center, but may be in the southeastern direction and with a velocity component to the eastward direction speed up the Earth's rotation. When accelerating the Earth's rotation speed, the Plate drift speed will be accordingly accelerated? The Deccan LIPs caused by the "Collisions Aggregation Effect" of the Chicxulub impact will also be the driving force to promote the Indian Plate to speed up the drift? In addition, the Shiva Crater impact incident will also prompt the Indian Plate to speed up drift?

(vi). At the $\mathrm{K} / \mathrm{T}$ boundary period, about $65 \mathrm{Ma}$, the occurrence of mass extinction event, the dinosaurs cluster-based extinction, and also provided a lot of evidence
[40]. At this point, the author believes that the corresponding evidence shows that there may indeed be a celestial body impact incident, the impact point may also be located in the Chicxulub crater. However, for those creatures extinct with dinosaurs as the main species, they were not extinct in a flash and should also have a great relation with the Deccan LIPs caused by the "Collisions Aggregation Effect" of the Chicxulub crater impact.

\section{Conclusion}

Combined with the full text of the research results, the author came to the following understanding:

(i). The main eruption time of the Deccan LIPs is $66 \mathrm{Ma}$, while the Chicxulub crater was formed at about $65 \mathrm{Ma}$ in approximate time; (ii). At 65Ma, the Deccan LIPs are located at $35^{\circ} \mathrm{S}, 65^{\circ} \mathrm{E}$, while the Chicxulub Crater is located at $20^{\circ} \mathrm{N}$, $50^{\circ} \mathrm{W}$, both of which have the characteristics of the distribution of nonlinear "Collisions Aggregation Effect" on the Earth; (iii). A Severe meteorite impact occurred at the Chicxulub crater in the Gulf of Mexico, causing "Collisions Aggregation Effect", which may be an important reason for the formation of the Deccan LIPs; (iv). The velocity vector direction of the Chicxulub meteorite may not be exactly pointing to the Earth's center, but is a little south-easterly direction; (v). Using the "Collisions Aggregation Effect" for the "impact point" or "collisions aggregation point" geographic location constraints, but also should taking into account the celestial body impact velocity vector direction; (vi). May be precisely because of the meteorite impact and the Deccan LIPs formed by the "Collisions Aggregation Effect" of the Chicxulub crater impact caused the massive dinosaur-based mass extinctions at the $65 \mathrm{Ma}$ of the $\mathrm{K} / \mathrm{T}$ boundary and accelerated the Indian Plate drift.

\section{Acknowledgements}

I thank Profs. Peng Mingxin and Ma Shaochun for their encouragement and guidance. I would also like to thank Dr. Chen Zailin for his firm support for the thesis hypothesis and finding evidence. Also thanks to Professor Zuo Qionghua and Yang Xiaofeng for my research support. Thanks also to the Science and Technology Innovation Fund of the Yunnan Provincial Bureau of Geology and Mineral Resources for my tremendous help.

\section{References}

[1] Boslough, M. B., Chael, E. P., Trucano, T. G., Crawford, D. A., Campbell, D. L., 1996. Axial focusing of impact energy in the Earth's interior; a possible link to flood basalts and hotspots. In: Ryder, G., Fastovsky, D., Gartner, S. (Eds.), The CretaceousTertiary Event and other Catastrophes in Earth History, Special Paper - Geological Society of America vol. 307. pp. 541-550. strophes in Earth History, edited by G. Ryder, D. Fastovsky, and A. Gartner, Geol. Soc. of Am. Spec. Pap., 307, 541-550. 
[2] LIU Chenming, YANG Demin, MA Shaochun. 2015. New ideas on the genesis of Emeishan basalt-the effect of collision and coalescence caused by the collision of celestial objects [J]. Mineral Resources And Geology, 29 (5):585-590. (in Chinese with English abstract).

[3] Liu Chenming. 2018. The New Hypothesis of the Origin to the Emeishan LIP: Because of the "Collisions Aggregation Effect" of a Meteorite Impact [J]. Earth Sciences. Vol. 7, No. 1, pp. 34-41. doi: 10.11648/j. earth.20180701.16.

[4] Liu Chenming, Yang Demin. 2018. Research on Paleogeography Recovery of "Impact Point" Based on "Collisions Aggregation Effect" [J]. Earth Sciences. Vol. 7, No. 2, pp. 58-63. doi: 10.11648/j.earth.20180702.13.

[5] Hartmann, W. K. 1965. Terrestrial and lunar flux of large meteorites in the last two billion years [J]. Icarus, 4 (2):157-165.

[6] Ren Zhenqiu. Will the asteroid hit the Earth? Science and Technology Daily, October 25, 1994, second edition (in Chinese).

[7] XIA Lin-qi, XU Xue-yi et al. 2012. Comparison of Three Large Igneous Provinces (Emeishan, Siberia, Deccan) in Asia [J]. NORTHWESTERN GEOLOGY. 45 (2):1-26. (in Chinese with English abstract).

[8] Alvarez L W, Alvarez W, Asaro F, et al. 1980. Extraterrestrial causes of the Cretaceous-Tertiary extinction [J]. Science. 208: 1095-1108.

[9] Pens, Z. X., Mahoney. J. J. 1995. Drillhole Isvas from the northwestern Dccan Traps, and the evolusion od Reunion hotspot mantle $[\mathrm{J}]$. Earth and Planetary Science Letters, 134:159-185.

[10] Pens, Z. X., Mahoney. J. J. 1994. Hooper, P. R., Harric, S., Besne, J. E., A role for lower continental crust in flood basalt genesis? Isotopic and incompatible element study of the lower six formations of the western Deccan Trap [J]. Geochimica et Cosmochimica Acta. 58:267-288.

[11] Sheth, H. C., Mahoney. J. J., Chandrasekhacam, D. 2004. Geochemical stratigraphy of Deccan flood basalts of the Bijasan Ghat section. Satpura Range, India [J]. Jourhal of Asian Earth Sciences. 23:127-139.

[12] Singh, R. N, Gupta, K. R. 1994. "Workshop yields new insight into volcanism at Deccan Traps, India" $[\mathrm{J}]$. Eos. 75:356.doi:10.1029/94EO01005.

[13] Dessert, Céline, Dupréa, Bernard, Françoisa, Louis M. Schotta, Jacques, Gaillardet, Jérôme, Chakrapani, Govind, Bajpai, Sujit. 2001. "Erosion of Deccan Traps determined by river geochemistry: impact on the global climate and the $87 \mathrm{Sr} / 86 \mathrm{Sr}$ ratio of seawater" [J]. Earth and Planetary Science Letters. 188: 461.

[14] https://newsoffice.mit.edu/2014/volcanic-eruption-dinosaur-ex tinction-1211 What really killed the dinosaurs? Before an asteroid wiped out the dinosaurs, Earth experienced a short burst of intense volcanism." Jennifer Chu. "MIT News Office," 11 December 2014.

[15] Baksi, A. K. 1994. Geochronological studies on whole-rock basalts, Deccan Traps. Indla-evaluation of the timing of volcanism relative to the K-T boundary [J]. Earth and Planetary Science Letters. 121:43-56.
[16] Baksi, A. K., Ferrar, E. 1991. Ar/Ar dating of the Siberian Traps, USSR: evalustion of the ages of the two main extinction events relative to episodes of flood basalt volcanism in the USSR and Deccan Traps. India [J]. Geology. 19:461-464.

[17] Besu, A. R. Renne, P. R., Dasgupta, D. K., Teichmann. F., Poreda, R. J. 1993. Early and late alkali igneoua pulses and a high-3He plume origin for the Deccan flood basalts $[\mathrm{J}]$. Science. 261:902-906.

[18] Widdowson, M., Pringle, M. S., Fernandez, O. A. 2000. A post K-T boundary (Early Palaeocene) age for Deccan-type feeder dykes, Goa, India [J]. Journal of Petrology. 41:1177-1194.

[19] Mitchell, C., Widdowson, M. 1991. A Geological map of the Southern Deccan Traps, India and its structural implications [J]. Journal of the Geological Society (London). 148:495-505.

[20] Lightfoot, R. C., Hawkesworth, C. J., Scthna, S. F. 1987. Petrogenesis of rhyolites and trachytes from the Deccan Trap: $\mathrm{Sr}, \mathrm{Nd}$ and $\mathrm{Pb}$ isotope and trace element evidence [J]. Contributions to Mineralogy and Petrology. 95:44-54.

[21] Sethna, S. F. 1999. Geology of Mumbai and surrounding areas and its position in the Deccan volcanic stratigraphy, India [J]. Journal of the Geological Society of India. 53:359-365.

[22] Sheth, H. C., Pande K., Bhutani, R. 2001. ${ }^{40} \mathrm{Ar}-{ }^{39} \mathrm{Ar}$ ages of Bombay trachytes: evidence for a Palaeocene phase of Deccan volcanism [J]. Geophysical Research Letters. 28:3513-3516.

[23] Cripps, J. A, 2002. Environmental impact of Deccan Trap flood basalt volcanism: assessment of regional floral responses to late Cretaceous-early Tertiary activity $[\mathrm{M}]$. PhD Thesis. The Open University, Milton Keynes, UK.

[24] Tatsumi, Y., Eggins, S. M., Subduction Zone Magmatism [M]. Blackwell Science, Cambridge, 1995, 211pp. Todal, A., Eldholm, O. 1998. Continental margin of western India and Deccan large igneous province [J]. Marine Geophysical Researches, 20:273-291.

[25] Saunders, A. D., Jones, S. M., Morgan, L. A., Pierre, K. L., Widdowson, M., Xu, Y. G. 2007. Regional uplift associated with continental large igneous provinces: The role of mantle plumes and the lithosphere [J]. Chemical Geology. 241:282-318

[26] "Chicxulub". Earth Impact Database. University of New Brunswick. Retrieved December 30, 2008.

[27] Amos, Jonathan (May 15, 2017). "Dinosaur asteroid hit 'worst possible place'"-via www.bbc.com.

[28] St. Fleur, Nicholas (17 November 2016). "Drilling Into the Chicxulub Crater, Ground Zero of the Dinosaur Extinction". The New York Times. Retrieved 4 November 2017.

[29] Becker, Luann. 2002. "Repeated Blows". Scientific American. 286 (3): 76-83. Bibcode: 2002 SciAm.

286c.76B.doi:10.1038/scientificamerican0302-76. PMID

11857903. Retrieved January 28, 2016.

[30] Adrian P. Jones. 2005. Meteorite Impacts as Triggers to Large Igneous Provinces [J]. ELEMENTS, VOL. 1, pp. 277-281.

[31] HOU Fanghui, ZHANG Xunhua, et al. 2014. Paleogeographic reconstruction and tectonic evolution of major blocks in China since Paleozoic [J]. Marine Geology \& Quaternary Geology, 34 (6): 9-26. (in Chinese with English abstract). 
[32] Li Jianghai, Wang Honghao et al. Discussion on global tectonics evolution from plate reconstruction in Phanerozoic. ACTA PETROLEI SINICA [J]. 35 (2):207-218. (in Chinese with English abstract).

[33] Chatterjee, S. 1997. Multiple impacts at the KT boundary and the death of the dinosaurs. Proceedings of the 30th International Geological Congress. 26:31-54. last accessed 2012-02-01.

[34] Chatterjee, S., N. Guven, A. Yoshinobu, and R. Donofrio. 2006. Shiva Structure: a possible KT boundary impact crater on the western shelf of India. Museum of Texas Tech University Special Publications [J]. 50, 39pp.

[35] Stanley, S. M. 2007. An analysis of the history of marine animal diversity. Paleobiology [J], 33: 1-55.

[36] McGhee, G. R., Clapham, M. E., Sheehan, P. M., et al. 2013. A new ecological-severity ranking of major Phanerozoic biodiversity crises. Palaeogeogr Palaeoclimat Palaeoecol [J], 370: 260-270.

[37] Ouyang Ziyuan, Guan Yunbin. 1992. Systematic catastrophic consequences of giant impacts in the evolution of the earth $[\mathrm{J}]$. Advance In Earth Sciences, 7 (1): 22-27. (in Chinese with English abstract).
[38] https://en.wikipedia.org/wiki/Indian Plate\#CITEREFKind200 7.

[39] Kind, Rainer (September 2007). "The fastest continent: India's truncated lithospheric roots". Helmholtz Association of German Research Centres. Retrieved January 2012.

[40] Rong J Y, Huang B. 2014. Study of Mass Extinction over the past thirty years: A synopsis (in Chinese). Scientia Sinica Terrae [J], 44:377-404. (in Chinese).

\section{Biography}

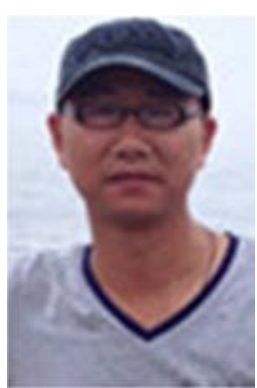

Liu Chenming (1984-), master, lecturer, mainly engaged in teaching and research work, research directions are: metallogenic regularity and metallogenic prediction, mineralogy, large igneous province (LIPs). The Papers from yunnan province bureau of geology and mineral resources of science and technology innovation fund, Fund number: 2016JJ02. 